\title{
NIERÓWNOŚCI PRZESTRZENNE ROZWOJU LOKALNEGO: WZORY ZRÓŻNICOWAŃ DOBROSTANU NA PRZYKŁADZIE WOJEWÓDZTWA PODKARPACKIEGO I MAZOWIECKIEGO
}

\begin{abstract}
Streszczenie
W ostatnich latach rośnie znaczenie badań i analiz obejmujących procesy rozwoju lokalnego. Jest to związane zarówno z nowymi nurtami w ramach ekonomii (tzw. nowa ekonomia geograficzna), jak i polityką rozwoju dotycząca przede wszystkim alokacji zasobów publicznych przez regionalne programy operacyjne. Ujęcie teoretyczne i podejście pragmatyczne uzupełniają się wzajemnie, łącząc idee tradycyjnych teorii lokacji (umiejscowienia inwestycji, działalności gospodarczej itp.) oraz podkreślają potrzebę badań ewaluacyjnych, ze szczególnym uwzględnieniem zróżnicowań pomiędzy lokalnościami. W artykule tym przedstawiono odpowiednie techniki wielowymiarowego pomiaru rozmaitych aspektów rozwoju lokalnego, jak i analizę nierówności obiektywnych i subiektywnych wskaźników rozwoju. Zaprezentowano także skale subiektywnego dobrostanu lokalnego i nierówności jego rozkładu, jak również problem współzależności przestrzennej rozkładu miar obiektywnych i subiektywnych. Wyniki badań przeprowadzonych w województwie podkarpackim i mazowieckim (znacznie różniących się pod względem rozwoju społeczno-gospodarczego) pozwoliły ukazać zalety tego podejścia do problemu zróżnicowań rozwoju lokalnego.
\end{abstract}

Słowa kluczowe: nierówności rozwoju, wielowymiarowy indeks deprywacji lokalnej, dobrostan subiektywny, dekompozycja nierówności przestrzennych

\section{SPATIAL INEQUALITIES OF LOCAL DEVELOPMENT: PATTERNS OF WELL- BEING DISPARITIES (CASE OF PODKARPACKIE AND MAZOWIECKIE VOIVODSHIP)}

\section{Summary}

Recent years have seen a growing importance of research and analysis related to local development processes. It is connected both with new trends within economics (the so-called new geographical economics) and development policies which primarily concern the allocation of public resources by regional operational programs. The theoretical and the pragmatic approaches complement each other by combining the ideas of the traditional theory of location (location of investment, economic activity, etc.), and emphasize the need for evaluation research, with particular attention to differences among localities. The paper presents appropriate techniques of multidimensional measurement of various aspects of local development, and an analysis of inequalities between objective and subjective indicators of development. Also discussed are scales of subjective local well-being and inequalities of its distribution, as well as the issue of spatial interdependence of

\footnotetext{
${ }^{1}$ dr hab. prof. W. Okrasa - Wydział Nauk Historycznych i Społecznych, Uniwersytet Kardynała Stefana Wyszyńskiego w Warszawie, Główny Urząd Statystyczny w Warszawie; e-mail: w.okrasa@uksw.edu.pl; dr Marek Cierpiał-Wolan - Zakład Statystyki i Ekonometrii, Uniwersytet Rzeszowski, Urząd Statystyczny w Rzeszowie; e-mail: m.wolan@stat.gov.pl.
} 
distribution of objective and subjective measures. The results of the surveys carried out in Podkarpackie and Mazowieckie voivodeships, which differ significantly in terms of socio-economic development, reveal the advantages of the presented approach when applied to the disparity in local development.

Key words: development inequalities, multidimensional index of local deprivation, subjective wellbeing, decomposition of spatial inequalities

\section{Wstęp}

Procesy rozwoju lokalnego stają się obiektem głównego nurtu badań ekonomiczno-statystycznych o coraz szerszym tematycznie spektrum zainteresowań. Z jednej strony, jest to wyrazem rosnącego znaczenia przypisywanego im przez współczesne koncepcje wzrostu i rozwoju - przede wszystkim w ramach tzw. nowej ekonomii geograficznej [Capello, Nijkamp, 2009]. Z drugiej strony, jest to rezultat roli nadawanej im w ramach pragmatycznie zorientowanej polityki rozwoju, w tym decyzji dotyczacych alokacji zasobów publicznych przez regionalne programy rozwojowe. Ujęcia te uzupełniaja się wzajemnie, wzmacniając znaczenie i rolę lokalnych (w tym endogenicznych) procesów rozwojowych. Po pierwsze, łącząc idee tradycyjnych teorii lokacji (umiejscowienia inwestycji, działalności gospodarczej itp.) z modelami rozwoju uwzględniającymi specyfikę ,przestrzeni”, czyli niejednorodność jednostek terytorialno-administracyjnych (z ich efektami zewnętrznymi itp.), [Capello, 2009] dostarczają teoretycznych podstaw do koncentrowania analiz na możliwie niskim szczeblu agregacji terytorialnej (jak NTS5/LAU2 - gmina). Po drugie, akcentując potrzebę badań ewaluacyjnych, skłaniaja do skupienia uwagi na zróżnicowaniach pomiędzy „lokalnościami”, wraz z czynnikami odpowiedzialnymi za obserwowane nierówności.

Bogactwo zbieranych aktualnie danych w ramach statystyki publicznej (zasoby Banku Danych Lokalnych i pochodne bazy wskaźników - jak STRATEG opracowane przez GUS), [Rogalińska, 2013] sprzyja praktycznej realizacji takich przedsięwzięć i zarazem założeniu podejmowania dalszych badań, rozszerzających perspektywę analityczną w kierunku uwzględnienia złożoności procesów rozwoju lokalnego.

Niniejszy artykuł ma na celu uwzględnienie powyższych uwag i postulatów przez odwołanie się do odpowiednich technik wielowymiarowego pomiaru rozmaitych aspektów rozwoju lokalnego, jak również skoncentrowanie analizy na, szeroko rozumianych, nierównościach obiektywnych i subiektywnych wskaźników rozwoju. Obejmuja one zarówno charakterystykę niedostatków lokalności ${ }^{2}$, nazywanych także dalej wskaźnikami deprywacji lokalnej, jak i elementy postaw oraz opinii wyrażanych w miarach indywidualnego dobrostanu przez ich mieszkańców.

Uznając nierówności za kategorię, która syntetyzuje efekty przedsięwzięć rozwojowych i odzwierciedla różnice względne w poziomach rozwoju jednostek terytorialnych (jakimi są tutaj gminy), opracowanie niniejsze przyjmuje zarazem określoną wizję relacji pomiędzy wzrostem (i rozwojem) a nierównościami. Generalnie, jest ona zgodna z oczekiwaniami sugerowanymi przez tzw. hipotezę „krzywej Kuznetsa” (sformuło-

\footnotetext{
${ }^{2}$ Lokalność jest rozumiana jako łączna nazwa na różne ujęcia podmiotów w skali lokalnej (społeczność lokalna, władza lokalna itp.).
} 
waną oryginalnie dla całych gospodarek i mającą kształt odwróconego „u”, tzn. sugerującą występowanie ogólnie mniejszych nierówności dochodu na niższych oraz na wyższych poziomach dochodu/rozwoju, osiagających zaś wartości maksymalne dla wartości środkowych dochodów; np. Aghion i Commander [Aghion, Commander, 1999], pokazali, że w przypadku krajów Europy Centralnej i Wschodniej będących w okresie transformacji taka trajektoria nie wystapiła). Oczywiście, hipoteza powyższa została tutaj przywołana jedynie w jej funkcji heurystycznej, jako pomocna formuła interpretacyjna wyników miar nierówności, np. pomiędzy województwami.

Drugi problem, związany zazwyczaj z analizą nierówności przestrzennych, dotyczy tzw. postulatów $\beta$-konwergencji oraz $\sigma$-konwergencji, formułowanych w polityce spójności społecznej Unii Europejskiej. Alokacja publicznych środków rozwojowych, w szczególności pochodzenia unijnego, orientowana jest według pierwszej zasady, nakazującej oddolne wyrównywanie poziomów (np. niezrealizowanej w Polsce, przynajmniej na poziomie jednostek terytorialnych typu województwa czy podregionu, gdyź środki te trafiały przede wszystkim na tereny już bardziej rozwinięte [Gorzelak, 2009]). W konsekwencji spełnienia pierwszej zasady, należałoby oczekiwać malejaccych nierówności pomiędzy jednostkami ( $\sigma$-konwergencji). Wcześniejsze analizy wstępne dla gmin wykazały zmniejszenie różnic pomiędzy społecznościami lokalnymi w zakresie miar charakteryzujących wybrane aspekty warunków życia, ale tylko na skalę pilotażową [Okrasa i in., 2013].

Kolejny, metodologicznie ważny, problem, wiąże się z określeniem względnego znaczenia indywidualnych oraz grupowych (tj. na poziomie społeczności lokalnej) źródeł zmienności w zakresie związku pomiędzy typami miar deprywacji i dobrostanu. Wymaga to bowiem identyfikacji zmiennych na obu poziomach w modelach pozwalających na ocenę skutków zmienności dla każdego z typów miar. Ten rodzaj analizy podjęto tutaj bardziej w wersji opisowej niż inferencyjnej, która włączałaby modelowanie wielopoziomowe jako właściwy sposób ujęcia, zachodzącej w rzeczywistości, interakcji pomiędzy indywidualnym i społecznościowym poziomem czynników determinujących wartości obu typów miar [Okrasa, 2013].

W takim, z kolei, ujęciu kategoria nierówności wydaje się szczególnie przydatna w analizie opisowej rozwoju lokalnego. Nierówności są więc reprezentowane przez dwie miary. W odniesieniu do deprywacji lokalnej, spełniającej warunki formalne (jako skala typu ilościowego), jest to indeks Theila [Theil, 1967; Theil, 1979]. Natomiast w stosunku do subiektywnych skal typu porządkowego, służących charakteryzowaniu dobrostanu subiektywnego, jest to miara nierówności dla danych jakościowych AllisonaFostera [Allison, Foster, 2004].

Artykuł składa się z pięciu części. W pierwszej skrótowo przedstawiono pojęcia dotyczące rozwoju i dobrostanu, wraz z kwestiami ich operacjonalizacji za pomoca odpowiednich wskaźników. Następnie przeanalizowano miary typu obiektywnego rozwoju, reprezentowane tu przez wielowymiarowy indeks deprywacji lokalnej i skoncentrowane na nierównościach przestrzennych deprywacji lokalnej, głównie z punktu widzenia ich struktury. Przedmiotem kolejnej części uczyniono skale subiektywnego dobrostanu lokalnego i nierówności jego rozkładu, z uwzględnieniem specyfiki skal porządkowych. Problem współzależności przestrzennej rozkładu miar obiektywnych i su- 
biektywnych zilustrowano w ostatniej części, poświęconej wynikom analiz. W podsumowaniu podkreślono raczej wstępny, niż konkluzywny charakter otrzymanych wniosków. Warto przy tym zaznaczyć, że wyniki pozwoliły ukazać zalety prezentowanego podejścia do problemu zróżnicowań rozwoju lokalnego.

\section{Rozwój i dobrostan społeczności lokalnych}

\subsection{Ustalenia pojęciowe - taksonomia wskaźników}

Jak podkreślano, zastosowane tutaj ujęcie, polegające na pomiarze poziomu i zróżnicowania obiektywnych cech lokalności i subiektywnych ocen ich mieszkańców, ma charakter statyczny i pomiarowo-opisowy. Ma ono pozwolić na diagnozę stanu rozwoju jednostek terytorialnych (gmin), jednakże bez prób identyfikowania obserwowanych źródeł różnic między nimi. Oznacza to rezygnację z podejścia łączącego się z oszacowaniem wpływu konkretnego programu (interwencji) jako czynnika odpowiedzialnego za zachowanie się miar nierówności na określonym obszarze (wyodrębnionym poprzez implementację specyficznego, podregionalnego programu). Mimo to, warto podkreślić, iż poprzestając na potencjalnej przydatności dla celów monitorowania, zastosowane podejście może zarazem być traktowane jako pierwszy etap w konstruowaniu, wykraczającego poza ten cel, systemu monitorująco-ewaluacyjnego w ramach geograficznie zorientowanej oceny programów rozwojowych.

Istotą niniejszego ujęcia, różniącego się od dominujących w dotychczasowej literaturze przedmiotu, jest akcentowanie w charakteryzowaniu rozwoju lokalnego konieczności równoczesnego uwzględnienia cech obiektywnych i subiektywnych, z których pierwsze są atrybutami lokalności (gmin), zaś drugie indywidualnych osób i gospodarstw domowych. Wymaga to odwołania się do swoistej triangulacji wskaźników, rozmaitych poziomów: mezo- i mikrojednostek - i o różnorodnym charakterze [Okrasa, 2013]. Schematycznym wyrazem takiej triangulacji wskaźników wraz z przykładami odpowiednich skal jest tabela 1., zawierająca kombinację poziomów jednostek analizy i miar [Okrasa, 2013].

Dwa spośród czterech typów wyłaniających się z utworzonej w ten sposób taksonomii wskaźników - leżące na głównej przekątnej - zasługują na szczególną uwagę i są przedmiotem dalszych analiz. Pozostałe dwa są potencjalnie przydatne i mogą być również stosowane do opisywania rozwoju lokalnego. Przykładowo, charakterystyki indywidualnych osób lub gospodarstw domowych, takie jak ich dochody czy wydatki, mogą być agregowane w zmienne przyporządkowywane całym lokalnościom. Z drugiej strony, subiektywne oceny zagrożeń czy ryzyka lokalnego typu strukturalnego (dotyczącego całej społeczności lokalnej) mogą być włączone do subiektywnych aspektów dobrostanu lokalnego. 
TABELA 1. Dobrostan subiektywny i obiektywny społeczności lokalnych - triangulacja wskaźnikowa rozwoju lokalnego

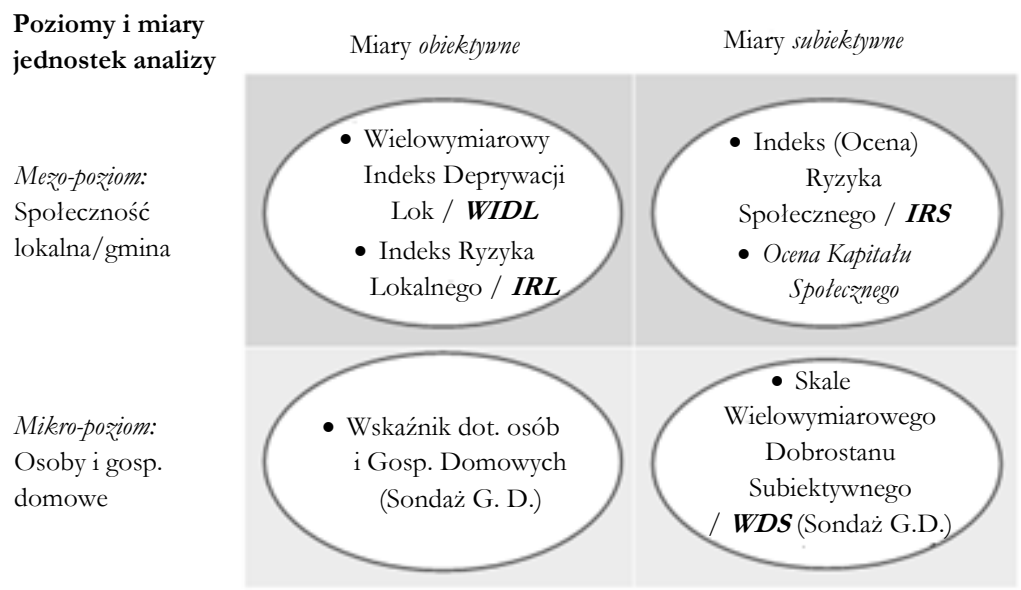

Źródło: [Okrasa, 2013].

\section{Obiektywne charakterystyki rozwoju lokalnego}

\subsection{Wielowymiarowy indeks deprywacji lokalnej}

Podstawową miarą dobrostanu obiektywnego społecznośc1 Iokalnej jest wielowymiarowy indeks deprywacji lokalnej, skonstruowany na bazie metodologii postulującej identyfikowanie lokalnej deprywacji (pockets of local deprivation), [Okrasa $i$ in., 2006] jako wskaźnika ich realnego „zapotrzebowania na rozwój”. Miary tego typu, dazżąc do uwzględnienia wieloaspektowej natury deprywacji (w znaczeniu ekonomicznym), [Atkinson, 2003], odwołuja się do technik skalowania wielowymiarowego, pozwalającego na redukcję znacznej liczby cech dostępnych w istniejących bazach danych (typu BDL) dzięki niearbitralnemu wyborowi tych tylko, które w sposób istotny składają się na łączną charakterystykę mierzonego aspektu.

Zastosowana w tym celu analiza czynnikowa, w wersji konfirmacyjnej (BDL, dane dla lat 2008 i 2010), polega tutaj na selekcji wybranych cech do pierwszego czynnika dla wyodrębnionych 11 wymiarów deprywacji lokalnej na podstawie wartości ładunków czynnikowych [Okrasa, Gudaszewski, 2013]. Zostały one wyszczególnione na rysunku 1., przedstawiającym ich wartości przeciętne jako efekt wieloetapowej procedury, na którą składały się:

- $\quad$ wstępny wybór dziedzin życia, w których można zidentyfikować deprywację;

- $\quad$ selekcja wskaźników w ramach każdej z dziedzin na podstawie analizy czynnikowej (metoda głównych składowych); 
- $\quad$ normowanie wartości poszczególnych wskaźników (uzupełniająca procedura, sugerowaną czasem w literaturze, jest tzw. procedura skracania - shrinkage, która jest stosowana do nieregularnych rozkładów, z reguły rzadkich przypadków występowania niektórych cech. Jest ona istotna wówczas, gdy wskaźnik występuje jako predyktor w ujęciach modelowych), [OCSI, 2008];

- agregacja wskaźników w indeks dla danej dziedziny;

- $\quad$ unormowanie wskaźników dla każdej dziedziny;

- agregacja wskaźników w kompozytowy indeks globalny.

RYSUNEK 1. Wielowymiarowy indeks deprywacji lokalnej (WIDL) - dziedziny składowe

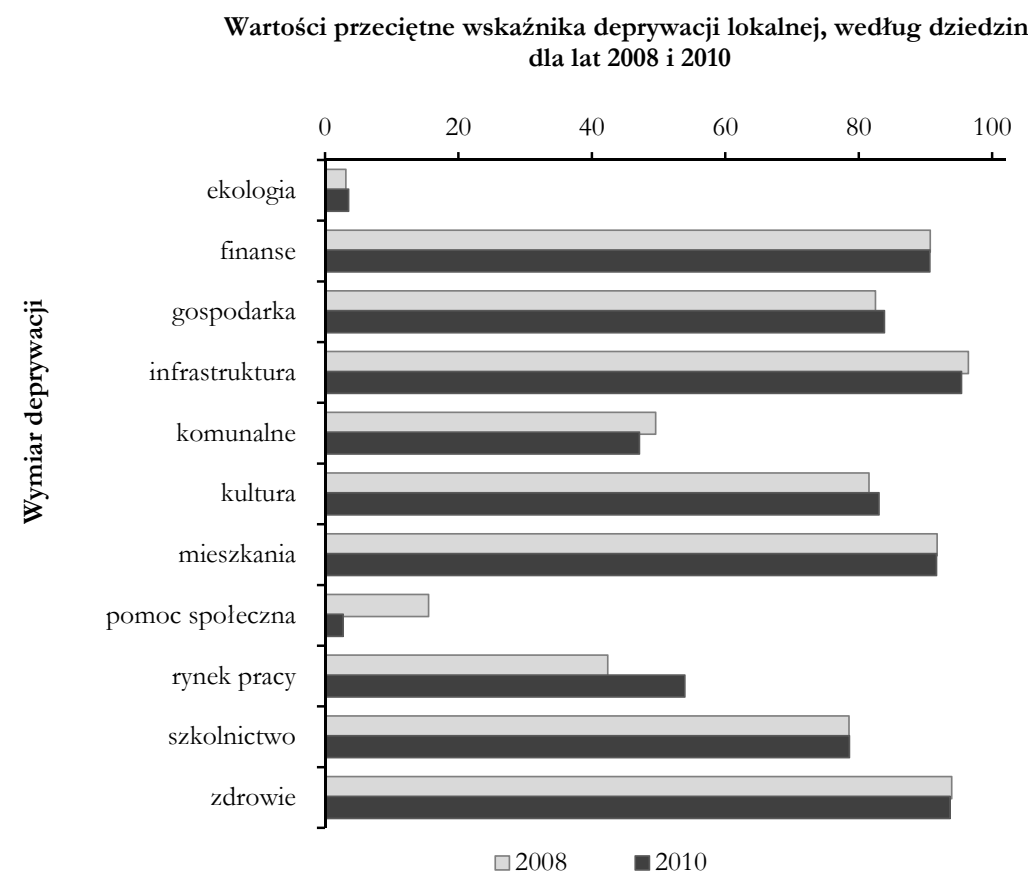

Źródło: [Okrasa, Gudaszewski, 2013].

Wartości WIDL zostały obliczone dla każdej z 2478 w 2008 roku (2 479 w 2010 roku) gmin w Polsce. Pozwoliło to na porównanie zróżnicowań pomiędzy nimi w terminach poszczególnych wymiarów (ekologia, finanse, gospodarka, infrastruktura, instalacje komunalne, kultura, mieszkania, pomoc społeczna, rynek pracy, oświata i wychowanie, zdrowie) oraz na skali łącznej (deprywacji lokalnej), która spełnia warunek rzetelności (alfa-Cronbacha waha się wokół 0,75, zależnie od włączenia lub wyklu- 
czenia ekologii jako wymiaru negatywnie skorelowanego z pozostałymi i jedynego rosnącego wraz z klasą wielkości miejscowości) ${ }^{3}$.

\subsection{Analiza zróżnicowania deprywacji w województwach: mazowieckim i podkarpackim}

Poziom i struktura przestrzenna nierówności w zakresie deprywacji lokalnej na poziomie gmin jest charakteryzowana za pomocą indeksu Theila [Theil, 1967; Teil, 1979], wybranego ze względu na jego własności interpretacyjne w odniesieniu do jednostek przestrzennych. Wartość całkowitej nierówności można rozdzielić na wartości „między” grupami i „wewnątrz” grup w sposób łączny i wyczerpujący. Grupy te stanowią podzbiory zbioru jednostek przestrzennych (tutaj powiaty jako zbiory gmin), [Rey, 2004; Okrasa, Gudaszewski, 2013].

Całkowita nierówność deprywacji łącznej powiatu dana jest wyrażeniem [Rey, 2004, s. 194]:

gdzie:

$$
T=\sum_{i=1}^{n} s_{i} \log \left(n s_{i}\right),
$$

$n$ jest liczba gmin w powiecie,

$s_{i}$ jest jej frakcją w sumie deprywacji danego podzbioru gmin (podregionu):

gdzie:

$$
s_{i}=\frac{y_{i}}{\sum y_{i}}
$$

$y_{i}$ oznacza deprywację $\mathrm{w} i$-tej gminie.

Obliczone wielkości deprywacji lokalnej nie są wysokie - wynoszą one dla lat 2008 i 2010, odpowiednio $T_{08}=0,00137$ i $T_{10}=0,00102$. Możliwość przedstawienia ich jako sumy nierówności „między” podgrupami (powiatami) i „wewnątrz” podgrup (powiatów) pozwala na określenie struktury deprywacji lokalnej.

Warto zauważyć, iż nieco niższy poziom zróżnicowania w zakresie deprywacji łącznej pomiędzy gminami w 2010 roku może wskazywać na przeważanie tendencji do $\sigma$-konwergencji nad $\beta$-konwergencja (co, miało miejsce w przypadku Polski, według opracowania Banku Światowego), [Gorzelak, 2009].

Analiza strukturalna nierówności przestrzennych bazuje na jej addytywności: $T=T_{B}+T_{W}$, gdzie $T_{B}$ oznacza nierówności „między” jednostkami przestrzennego podziału, zaś $T_{W}$ nierówności „wewnątrz” tych jednostek, takich jak powiaty grupujące gminy jako swoje elementy w ramach województwa lub jak województwa grupujące gminy z pominięciem powiatów w ramach całego kraju. Wówczas $T$ może być przed-

3 Przykładowo, dane włączone do ekologii odnoszą się do następujących, wybranych cech: emisja zanieczyszczeń pyłowych i gazowych w tonach w przeliczeniu na 100 ha powierzchni całkowitej gminy; ścieki (przemysłowe i komunalne) w dam ${ }^{3}$ wymagające oczyszczania, odprowadzone do wód lub do ziemi w przeliczeniu na 1000 ludności; zakłady wytwarzające odpady w przeliczeniu na 1000 ludności; odpady (przemysłowe $\mathrm{i}$ komunalne) w tys. ton wytworzone w ciagu roku w przeliczeniu na 1000 ludności. 
stawione jako dekompozycja $T$ na powyższe części dla przypadku łączenia gmin według powiatów, w następujący sposób [Rey, 2004, s. 194-198]:

gdzie:

$$
T=\sum_{g=1}^{\omega} s_{g} \log \left(\frac{n}{n_{g} s_{g}}\right)+\sum_{g=1}^{\omega} s_{g} \sum_{i \in g} s_{i, g} \log \left(n_{g} s_{i, g}\right),
$$

$\omega$ - liczba powiatów w województwie,

$g$ - numer powiatu,

$n$ - liczba gmin w województwie,

$n_{g}-$ liczba gmin w powiecie $g$,

$s_{i, g}$ - udział $i$-tej gminy z powiatu $g$ w sumie deprywacji gmin w powiecie $g$,

$s_{g}$ - udział $g$-tego powiatu w sumie deprywacji gmin w województwie.

Uzyskane wyniki są przedstawione w tabeli 2 .

TABELA 2.

Struktura nierówności przestrzennych deprywacji lokalnych (gmin) „wewnątrz” powiatów i „między” nimi - w latach 2008 i 2010

\begin{tabular}{|c|c|c|c|}
\hline & Lącznie & Pomiędzy & Wewnątrz \\
\hline 2008 & 0,001371 & 0,000708 & 0,000663 \\
2010 & 0,001029 & 0,000497 & 0,000532 \\
\hline
\end{tabular}

Źródło: [Okrasa, Gudaszewski, 2013].

Porównanie wartości „wewnątrz” grup i „między” grupami (w powiatach) pozwala zauważyć, że zanotowany spadek nierówności całkowitych (o około 25\%) w latach 2008-2010 może być przypisany przede wszystkim (chociaż nie wyłącznie) redukcji zróżnicowań deprywacji pomiędzy powiatami. Spadek zróżnicowania, zdecydowanie przeważający między powiatami niż w obrębie powiatów, wyraził się odwróceniem proporcji - w 2010 roku zaczęły dominować różnice wewnątrz powiatów. Można to zinterpretować jako efekt odgórnego systemu alokacji środków rozwojowych, w którym gmina jest ogniwem końcowym. Odwrotnego wyniku można oczekiwać przy zastosowaniu systemu alokacji oddolnej albo po uwzględnieniu tylko tych programów, które były podejmowane z lokalnej inicjatywy.

Uzupełnieniem powyższych wyników jest analogiczna analiza strukturalna nierówności deprywacji lokalnej, przeprowadzona w ramach województw (rysunek 2.). Umożliwia ona wyodrębnienie trzech grup województw, cechujących się odpowiednio:

- $\quad$ stosunkowo najwyższym poziomem łącznego zróżnicowania, z wyraźną dominacją nierówności „,wewnątrz” powiatów nad nierównościami „między” powiatami - są to województwa: pomorskie, zachodniopomorskie i dolnośląskie; podobną strukturą nierówności, ale o niższym poziomie łącznego zróżnicowania, cechują się województwa: lubuskie, lubelskie, podkarpackie i warmińsko-mazurskie;

- przewaga zróżnicowania „między” powiatami nad zróżnicowaniem „wewnątrz” nich - są to województwa: mazowieckie, wielkopolskie, śląskie; 
- $\quad$ względnie małym zróżnicowaniem „między” powiatami, jak i „wewnątrz” powiatów - województwa: łódzkie, małopolskie, świętokrzyskie, opolskie, podlaskie i kujawsko-pomorskie.

RYSUNEK 2.

Struktura nierówności przestrzennych wskaźnika deprywacji lokalnej w powiatach poszczególnych województw w 2010 roku

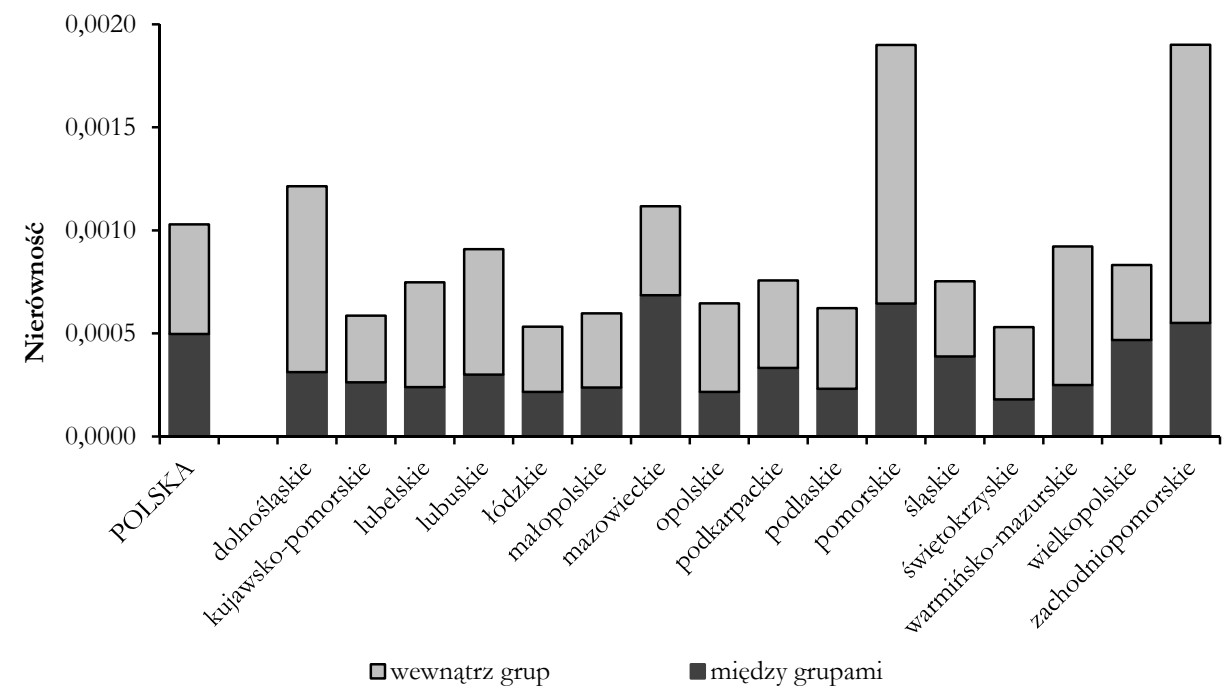

Źródło: [Okrasa, Gudaszewski, 2013].

\section{Dobrostan subiektywny - pomiar i zróżnicowanie}

\subsection{Charakterystyka indywidualnego dobrostanu subiektywnego w społeczności lokalnej}

Subiektywny dobrostan indywidualny wstępnie scharakteryzowano na podstawie badania pilotażowego gospodarstw domowych, obejmującego ponad 800 respondentów w podobnych proporcjach, w województwie podkarpackim (410) i mazowieckim (400). Próbę dobrano przez losowanie proste $\mathrm{z}$ warstwowaniem, a dane zbierano metodą kwestionariuszowa. Respondenci wypełniali ankietę, zawierająca ponad sto pytań, na temat: materialnych aspektów życia, aspektów społecznych i intelektualnych, satysfakcji z kluczowych dziedzin życia oraz przynależności i utożsamiania się z grupą społeczna. Pytania były sformułowane według formatu Likerta, dając możliwość udzielenia odpowiedzi wyrażającej stopień zgodności/niezgodności (od „Zdecydowanie zgadzam się" do „Zdecydowanie nie zgadzam się”), z oceną środkowa, określająca zdanie neutralne. Skonstruowane skale bazowały na modułach badań sondażowych Oxford Quality of Life Index and Dashboard (OXQOL), [Anand i in., 2010], których wersja, zmo- 
dyfikowana do warunków polskich, sprawdzana była w badaniu pilotażowym [Okrasa, 2013].

Generalnie, taka operacjonalizacja pojęcia dobrostanu subiektywnego zgadza się z rekomendacjami OECD [OECD, 2013], aby uwzględniać trzy kluczowe aspekty, za które uznaje się:

- ogólną ocenę swojego życia wraz z satysfakcją z pracy, zdrowia oraz satysfakcją $z$ dochodów itp. ${ }^{4}$;

- $\quad$ samopoczucie i afekty - pozytywne i negatywne - w tym: szczęście, zmartwienie, gniew itp.; aspekt ten, łączy się ogólnie ze stanami emocjonalnymi, w literaturze bywa nazywany hedonistycznym ${ }^{5}$;

- $\quad$ eudajmonię jako poczucie sensu i celu związane z osiaganiem zadowolenia z własnego życia jako podstawowym dążeniem każdego (racjonalnie działającego) człowieka.

Oprócz powyższych (klasycznych) miar dobrostanu indywidualnego, zastosowano także skalę „poczucia przynależności i identyfikacji” w odniesieniu do swojego otoczenia społecznego, nazywaną także w literaturze skala „,poczucia sensu społeczności lokalnej" Sense of Community (SCI), [Chavis i in., 2008] $]^{6}$.

Jakościowy charakter danych, posiadających nie tylko wymiar subiektywny, ale dających się wyrazić na skali porządkowej (bez możliwości obliczania momentów rozkładów), wskazuje, aby odwołać się do niestandardowych miar nierówności, z klasy miar pozycyjnych.

\subsection{Miary nierówności rozkładu dobrostanu subiektywnego}

Zgodnie z powyższymi uwagami, w analizie struktury nierówności rozkładu dobrostanu subiektywnego odwołano się do miar pozycyjnych, a dokładnie do, bazującej na medianie, miary Allisona i Fostera [Allison, Foster, 2004]. Uwzględnia ona rozrzut odpowiedzi (ocen) badanych, porównując ich zbieżność i rozproszenie.

Oznaczając przez $i=1, \ldots, n$ numer kolejnej kategorii (odpowiedzi), zaś przez $c_{i}$ ocenę wybrana przez respondenta $\mathrm{w}$ danym pytaniu, a przez $k$ kategorię mediany (tzn. taką, do której należy „osoba medianowa”), można średnią rozkładu ocen przedstawić jako:

$$
\mu_{X}(c)=\sum_{i=1}^{n} c_{i} f_{X}^{i},
$$

gdzie $f_{X}^{i}$ jest odsetkiem populacji w i-tej kategorii.

\footnotetext{
${ }^{4}$ Ze względu na szacowanie poziomu zadowolenia $z$ istotnych elementów życia, ten aspekt także bywa nazywany w literaturze dobrostanem ewaluowanym (evaluative well-being). Zob.: [Stone, Mackie, 2013].

5 Alternatywnym określeniem, występującym również od niedawna w literaturze, jest dobrostan doświadczany (experienced well-being/ExWB). Zob.: [Stone, Mackie, 2013].

"Skala „poczucia przynależności i identyfikacji”” zawiera na przykład stwierdzenia typu: „Członkowie tej społeczności reprezentują te same wartości, co ja”; „Przynależność do tej społeczności sprawia, że czuję się dobrze" itp.
} 
Średnia rozkładu ocen w kategoriach poniżej i powyżej mediany może być wyrażona następująco:

- poniżej mediany:

$$
\mu_{X}^{L}(c)=2\left(\sum_{i=1}^{k-1} c_{i}\left(F_{X}^{i}-F_{X}^{i-1}\right)+c_{k}\left(0,5-F_{X}^{k-1}\right)\right),
$$

- powyżej mediany:

$$
\mu_{X}^{U}(c)=2\left(\sum_{i=k+1}^{n} c_{i}\left(F_{X}^{i}-F_{X}^{i-1}\right)+c_{k}\left(F_{X}^{k}-0,5\right)\right),
$$

gdzie $c=\left(c_{1}, \ldots, c_{n}\right)$ jest to wektor ocen, natomiast $F_{X}^{i}$ oznacza dystrybuantę rozkładu zmiennej losowej $X$ przedstawiającej odpowiedzi (oceny) wybrane przez respondentów.

Zaproponowana przez Allisona i Fostera miara nierówności (AF) ma postać:

$$
I_{X}^{A F}(c)=\mu_{X}^{U}(c)-\mu_{X}^{L}(c) .
$$

Miara ta przyjmuje wartości z przedziału domkniętego i można ją unormować za pomoca prostej transformacji, jak niżej:

$$
I_{X}^{U(A F)}(c)=\frac{I_{X}^{A F}(c)}{c_{n}-c_{1}} \in[0,1] .
$$

Wówczas wartości tej miary mają następująca interpretację: jeśli wszyscy respondenci wybraliby tę samą odpowiedź, to nie wystąiłaby żadna nierówność i $I_{X}^{U(A F)}(c)=0$; jeżeli zaś dokładnie połowa respondentów wybrałaby najniższa, a druga połowa najwyższą ocenę (polaryzacja ocen), to $I_{X}^{U(A F)}(c)=1$. Miara ta nie zmienia się przy skalowaniu i translacji wektora ocen c. Nierówność dwóch rozkładów odpowiedzi, $X$ i $Y$, może być oceniona przez porównanie $I_{X}^{A F}(c)$ i $I_{Y}^{A F}(c)$. Jeśli $I_{X}^{A F}(c)>I_{Y}^{A F}(c)$, to rozkład ocen w grupie $X$ jest bardziej nierównomierny niż w grupie $Y$.

Miarę tę (w obydwu wersjach - nieunormowanej i unormowanej) wykorzystano do porównania wybranych aspektów dobrostanu indywidualnego (gospodarstw domowych) na podstawie danych z badania pilotażowego na Mazowszu i Podkarpaciu, opisanego wcześniej w punkcie 4.1. Przykładowe wyniki zaprezentowano na rysunkach: 4. - 6. Sa one poprzedzone rysunkiem 3., przedstawiającym rozkłady odpowiedzi na pytanie dotyczące oceny dojazdów do pracy, jako ilustracja charakteru tych pytań (Pytanie: „Proszę powiedzieć, na ile jest Pan(i) zadowolony(a) z wykonywania tych czynności przez siebie? W ocenie proszę posłużyć się pięciostopniową skala, gdzie 1 oznacza zdecydowanie niezadowalające, 2 - raczej niezadowalające, 3 - ani zadowalające, ani niezadowalające, 4 - raczej zadowalające, 5 - zdecydowanie zadowalające”).

$\mathrm{Na}$ rysunkach od 4. do 6. są przedstawione nierówności rozkładów ocen w zakresie: satysfakcji z wykonywania codziennych .czynności (rysunek 4.), wybranych aspektów życia (rysunek 5.), ogólnego poczucia dobrostanu (rysunek 6.).

Pokazane na rysunku 6. nierówności w zakresie rozkładu ocen na temat czynności należących do głównych typów działań wykonywanych na co dzień - takich jak: praca i dojazdy do niej, opieka nad dziećmi, prace domowe, kształcenie oraz edukacja i hobby - wykazują pewną tendencję do większego zróżnicowania wśród gospodarstw domowych na Mazowszu niż na Podkarpaciu. Pozostawiając kwestię wyjaśnienia tych różnic (co warte byłoby podjęcia w przypadku posłużenia się próbami repre- 
zentacyjnymi), wystarczy jedynie podkreślić, iż zastosowanie miary nierówności typu pozycyjnego jest także uzasadnione jej dostateczną wrażliwością na różnice występujące między rozkładami, nawet niezbyt dużymi, jak ilustruje to przypadek dojazdów do pracy (rysunki: 3. i 4.).

RYSUNEK 3. Rozkład ocen w kategorii dojazdów do pracy oraz średnie oceny dla danych województw

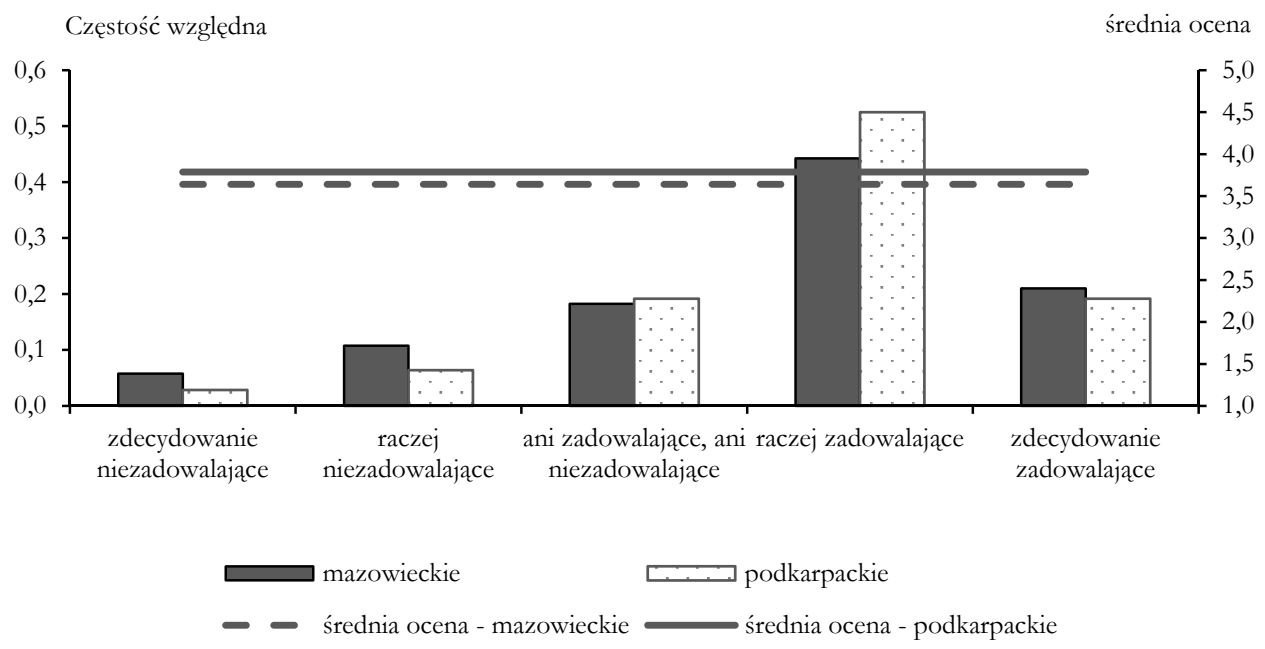

Źródło: opracowanie własne.

Nieco odmienne, ponieważ o niejednorodnym charakterze, tendencje są pokazane na rysunku 5., przedstawiającym nierówności w zakresie głównych aspektów życia - materialnym oraz społecznym i intelektualnym - uzupełnione o poczucie identyfikacji ze swoją społecznością lokalna. Zarówno w „społecznym i intelektualnym”, jak i „w przynależności i utożsamianiu się ze społecznością lokalną” rozrzut udzielanych odpowiedzi w województwie mazowieckim był większy niż w województwie podkarpackim. Z kolei, rozproszenie odpowiedzi na temat materialnego wymiaru życia było większe w województwie podkarpackim, odzwierciedlając bądź mniejszą nierówność w tym aspekcie na Podkarpaciu, bądź większą subiektywną awersję do nierówności na Mazowszu. Jest to kolejna obserwacja, sugerująca potrzebę odwołania się do dodatkowych danych (jako niemożliwa do wyjaśnienia na gruncie wynikowych danych pilotażowych).

Jeszcze bardziej zróżnicowane nierówności pomiędzy porównywanymi województwami są w zakresie dziesięciu pozycji składających się łącznie na skalę ogólnego poczucia dobrostanu. Przedstawiono je na rysunku 6. 
RYSUNEK 4.

Nierówności w satysfakcji z wykonywania codziennych czynności. Miara AF - województwa: podkarpackie i mazowieckie

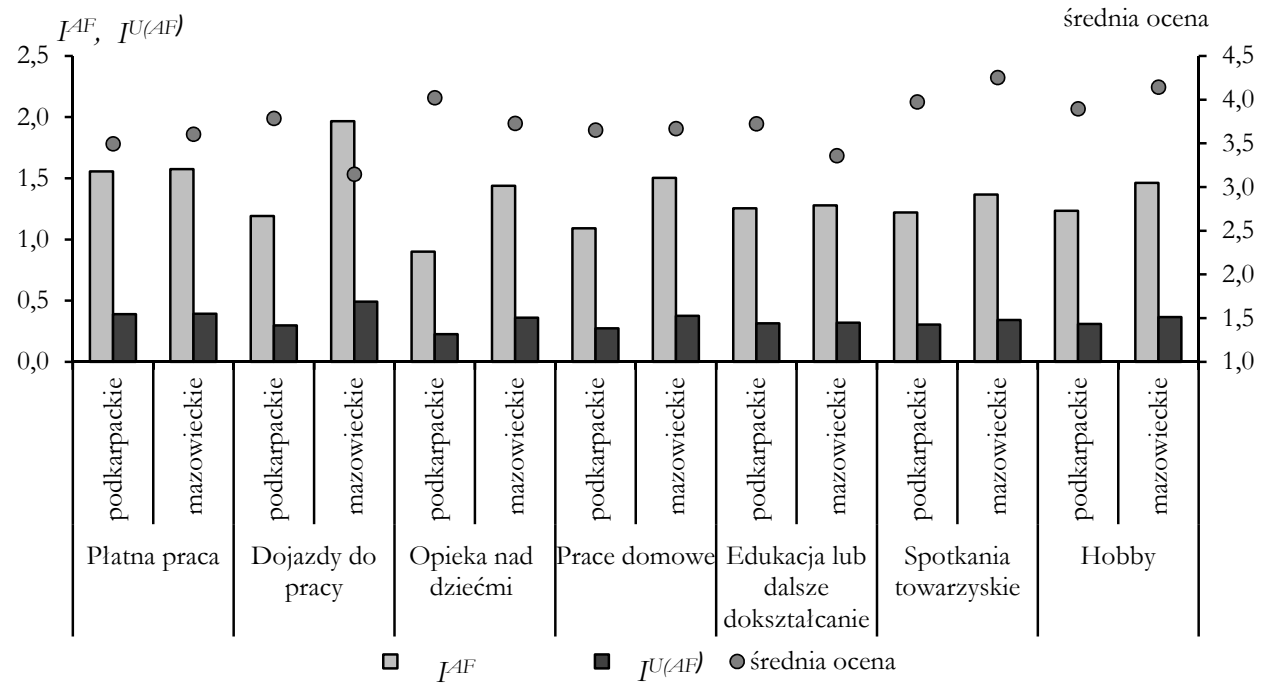

Źródło: [Okrasa, Cierpiał-Wolan, 2013, s. 18].

\section{RYSUNEK 5.}

Nierówności w wybranych aspektach życia

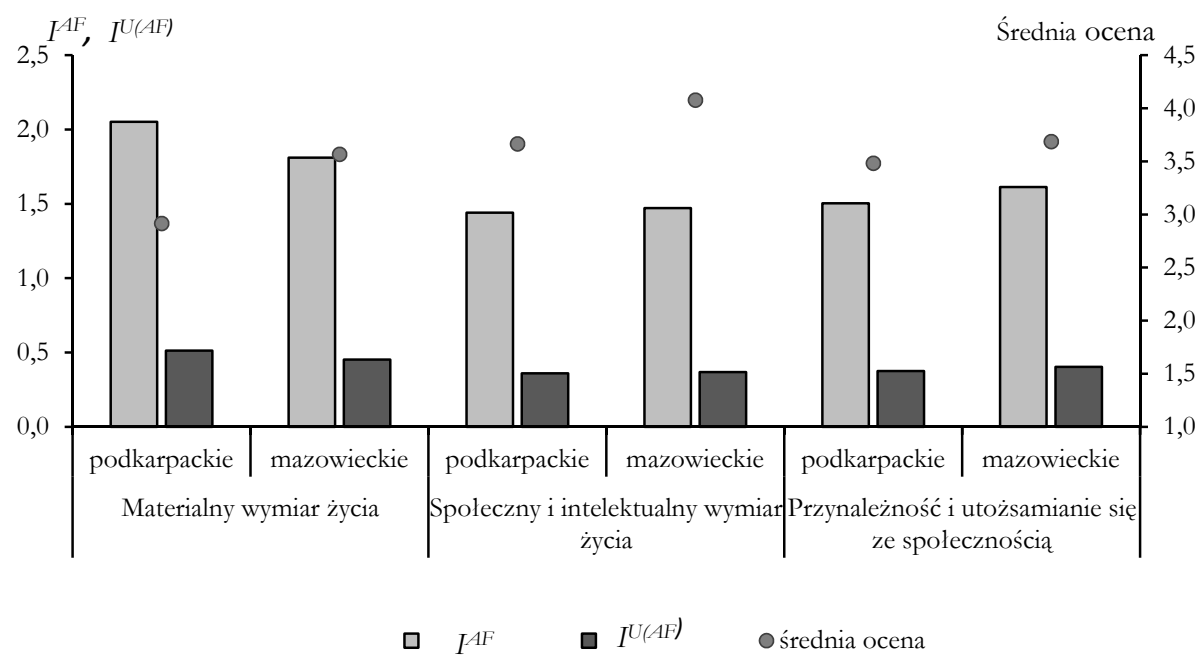

Źródło: [Okrasa, Cierpiał-Wolan, 2013, s. 20]. 

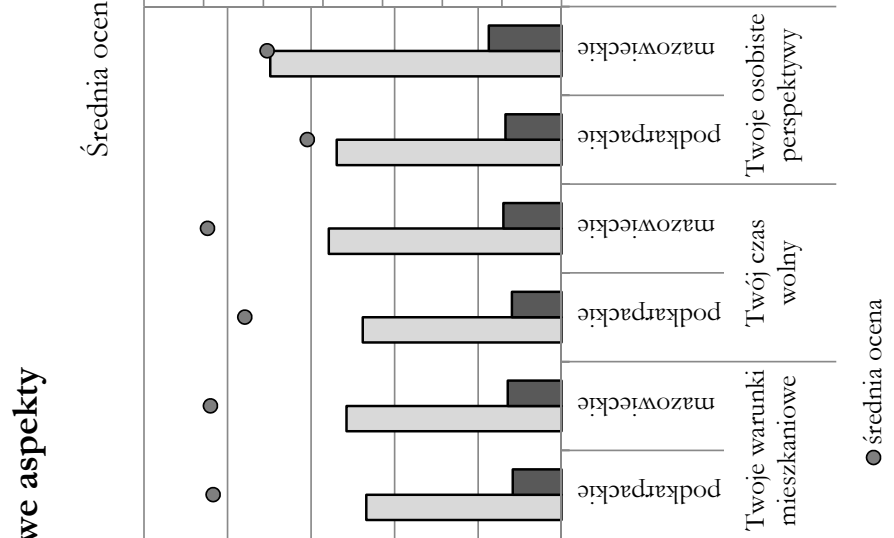

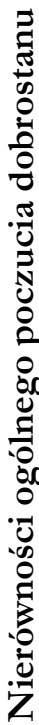

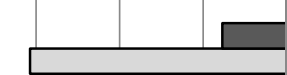

әгурวгмоzеш

:

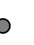

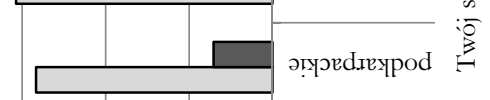

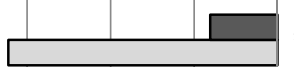

әгүววмМови

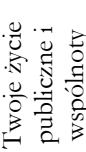

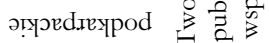

○

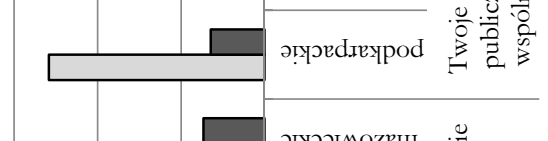

$\circ$
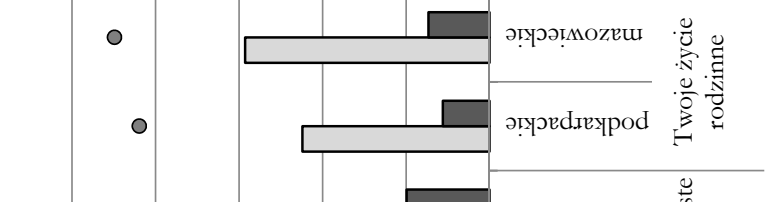

วгРววเМOZ૯น

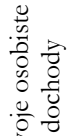

E

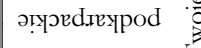

ㅁ 
Z punktu widzenia stopnia zróóżnicowania, zbiór podwymiarów (aspektów) dobrostanu wyszczególnionych na rysunku 6. podzielił się na dwie grupy. Do pierwszej należą te, w zakresie których bardziej nierównomiernie są rozłożone oceny respondentów na Podkarpaciu. Dotyczą one: pracy, dochodów oraz zdrowia i planów osobistych. Natomiast na Mazowszu występuje większe zróżnicowanie wśród respondentów w zakresie drugiej grupy: życia rodzinnego, udziału w sprawach publicznych, warunków mieszkaniowych oraz bardziej personalnych aspektów, takich jak: sen, czas wolny czy osobiste perspektywy.

\section{Analiza przestrzenna}

\subsection{Autokorelacja i klastry przestrzenne - statystyka I Morana}

W tej części poddano empirycznej analizie tezę głosząca, że zróżnicowanie miar dobrostanu - pojmowanego zarówno jako obiektywny atrybut całych społeczności lokalnych (jakim jest tutaj deprywacja lokalna gminy), jak też jako wyraz subiektywnych ocen mieszkańców na temat kluczowych aspektów dobrostanu indywidualnego - występuje w przestrzeni w sposób charakteryzujący się określonego typu wzorami albo klastrami przestrzennymi. W tym celu odwołano się do analizy uwzględniającej współrzędne geograficzne, za pomocą technik eksploracyjnej analizy danych przestrzennych (ESDA/Exploratory Spatial Data Analysis, z wykorzystaniem oprogramowania GeoDa), [Anselin i in., 2010].

Analiza ta bazuje na pojęciu autokorelacji przestrzennej, definiowanej w terminach statystyki I Morana, pozwalającej na identyfikację występowania globalnych oraz lokalnych klastrów przestrzennych [Aldstadt, 2010].

W pierwszym przypadku statystyka I Morana jest dana wyrażeniem:

$$
I=\frac{n}{W} \frac{\sum_{i=1}^{n} \sum_{j=1}^{n} w_{i j}\left(x_{i}-\bar{x}\right)\left(x_{j}-\bar{x}\right)}{\sum_{i=1}^{n}\left(x_{i}-\bar{x}\right)^{2}},
$$

gdzie:

$w_{i j}$ - waga połączeń pomiędzy jednostkami $i$ oraz $j$, w macierzy $n \times n$, gdzie $n-$ liczba jednostek, $W$ - suma wszystkich wag $w_{i j}$,

$x_{i}$ - obserwacja w gminie $i$,

$x_{j}$ - obserwacja w gminie $j$,

$\bar{x}$ - średnia arytmetyczna ze wszystkich badanych gmin.

Jeżeli statystyka globalna Morana ma wartość bliską jeden, to jednostki o tym samym poziomie cechy grupują się przestrzennie; wartość bliska minus jeden oznacza, że jednostki położone blisko siebie mają zróżnicowany poziom cechy; zaś przy zerze wartości cechy rozkładają się w przestrzeni w sposób losowy.

W drugim przypadku lokalna statystyka I Morana, która może być interpretowana jako dekompozycja globalnej statystyki I Morana, określona jest wzorem:

$$
I_{i}=\frac{n\left(x_{i}-\bar{x}\right) \sum_{j=1}^{n} w_{i j}\left(x_{j}-\bar{x}\right)}{\sum_{j=1}^{n}\left(x_{j}-\bar{x}\right)^{2}} .
$$


W przeciwieństwie do swojego prototypu, tj. współczynnika korelacji liniowej Pearsona, wartości przyjmowane przez statystykę I Morana nie są formalnie ograniczone do przedziału o krańcach -1 oraz 1, zależąc od wielkości próby, chociaż w praktyce najczęściej mieszczą się w tym przedziale. Statystykę lokalną I Morana oblicza się osobno dla każdego obiektu. Ma ona interpretację analogiczną do statystyki globalnej. Istotnym uzupełnieniem w analizie statystyki I Morana jest rysunek rozrzutu, ułatwiający interpretację badanych zależności w przestrzeni. Na osi x występują wartości cechy obiektu, zaś na osi y średnie wartości cechy u sasiadów oddalonych od ustalonego obiektu o nie więcej niż wartość krytyczną (odległość, dla której każdy obiekt ma w sąsiedztwie przynajmniej jeden inny obiekt). Na rysunku rozrzutu Morana występuje także linia regresji zmiennej Y względem zmiennej $\mathrm{X}$, której współczynnik nachylenia jest tożsamy ze współczynnikiem globalnej autokorelacji Morana.

\subsection{Przykłady zależności rozkładów przestrzennych dobrostanu}

Poniższe rysunki ilustrują wybrane rezultaty zastosowań analizy ESDA za pomoca programu obliczeniowego GeoDa, służącego: analizom przestrzennym, geowizualizacji i badaniu autokorelacji przestrzennych ${ }^{7}$. Warto zacząć od analizy dla jednej zmiennej, inspirowanej pytaniem o to, czy istnieje tendencja do współwystępowania w przestrzeni, tzn. do sąsiadowania ze sobą lokalności (gmin) o podobnym poziomie deprywacji lokalnej (np. biednych obok biednych i zamożnych obok zamożnych). Przybliżonej odpowiedzi na to pytanie dostarcza rysunek 7 .

RYSUNEK 7.

Rozrzut Morana wielowymiarowego indeksu deprywacji lokalnej (WIDL) dla gmin w województwie podkarpackim

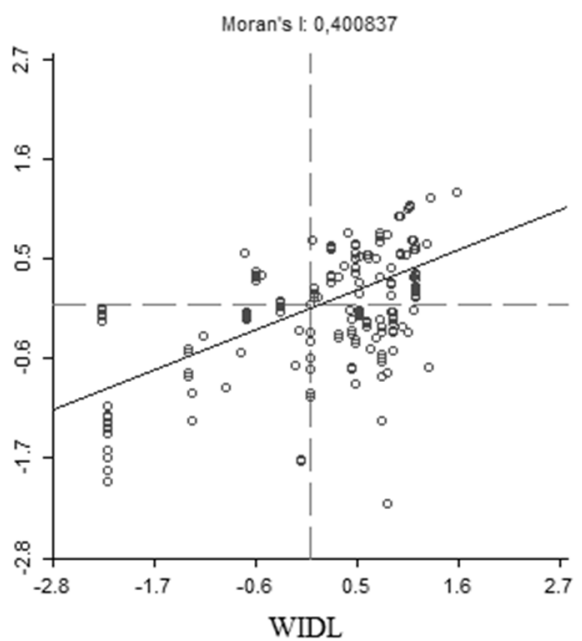

Źródło: opracowanie własne.

${ }^{7}$ Szerzej o zastosowaniu tego programu (freeware) w: [Fischer, Getis, 2010]. 
Istotnie występuje tendencja $(I=0,40)$ do sąsiadowania ze soba gmin o podobnym poziomie deprywacji/rozwoju, tzn. dodatnia zależność pomiędzy deprywacją danej gminy a deprywacja gmin sąsiednich. W szczególności gminy o deprywacji wyższej niż przeciętna mają tendencję do grupowania się (I ćwiartka). Gminy o względnie niskiej deprywacji rzadko sąsiadują z gminami o wysokiej deprywacji, co może świadczyć o przenikaniu pozytywnych procesów z gminy o mniejszym niedostatku do gmin ościennych (II ćwiartka).

Rysunek 8. odpowiada na pytanie, czy gminy o danym poziomie deprywacji lokują się przestrzennie wśród gmin o danym poziomie wielkości, charakteryzowanej liczebnością jej mieszkańców.

RYSUNEK 8.

Rozrzut Morana dla związku wielowymiarowego indeksu deprywacji lokalnej (WIDL) z wielkością populacji gminy w województwie podkarpackim

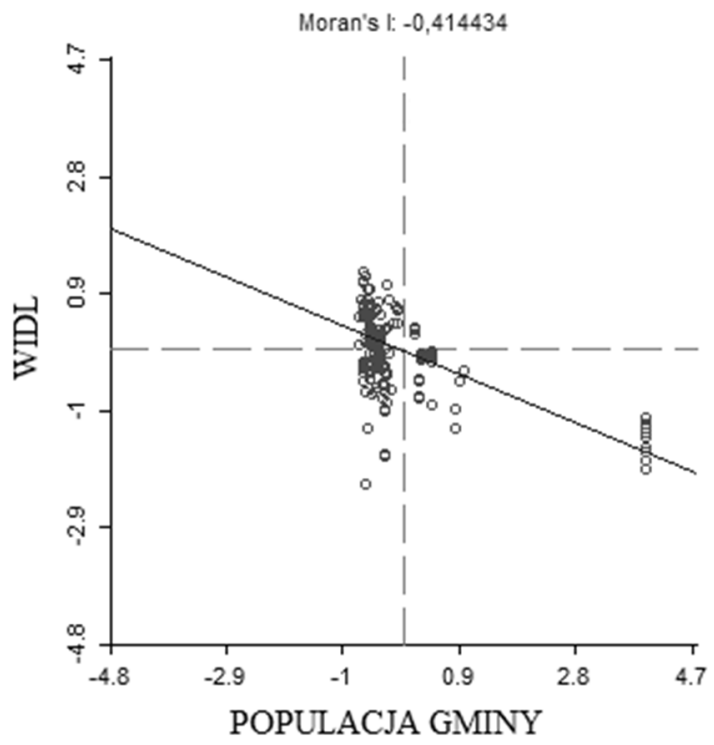

Źródło: opracowanie własne.

Bliskość dużych gmin jest akceleratorem spadku poziomu niedostatku w gminach sąsiednich (IV ćwiartka). Pierwsza ćwiartka rysunku nasuwa stwierdzenie, że im większa gmina, tym sąsiednie gminy mają niższą deprywację. Gminy o małej liczbie ludności często grupują się w obszary o wysokiej deprywacji.

Nieco bardziej złożony charakter zależności przedstawia rysunek 9., gdyż deprywacja lokalna (atrybut gminy) jest tutaj zarazem cechą kontekstową dla indywidualnego dobrostanu subiektywnego. Z uwagi na dysponowanie drugiego typu danymi tylko dla kilkunastu gmin na terenie województwa podkarpackiego, rezultaty te ograniczaja się do wybranych gmin. 
RYSUNEK 9.

Rozrzut Morana dla związku wielowymiarowego indeksu deprywacji lokalnej (WIDL) z subiektywnym dobrostanem $w$ wybranych gminach województwa podkarpackiego

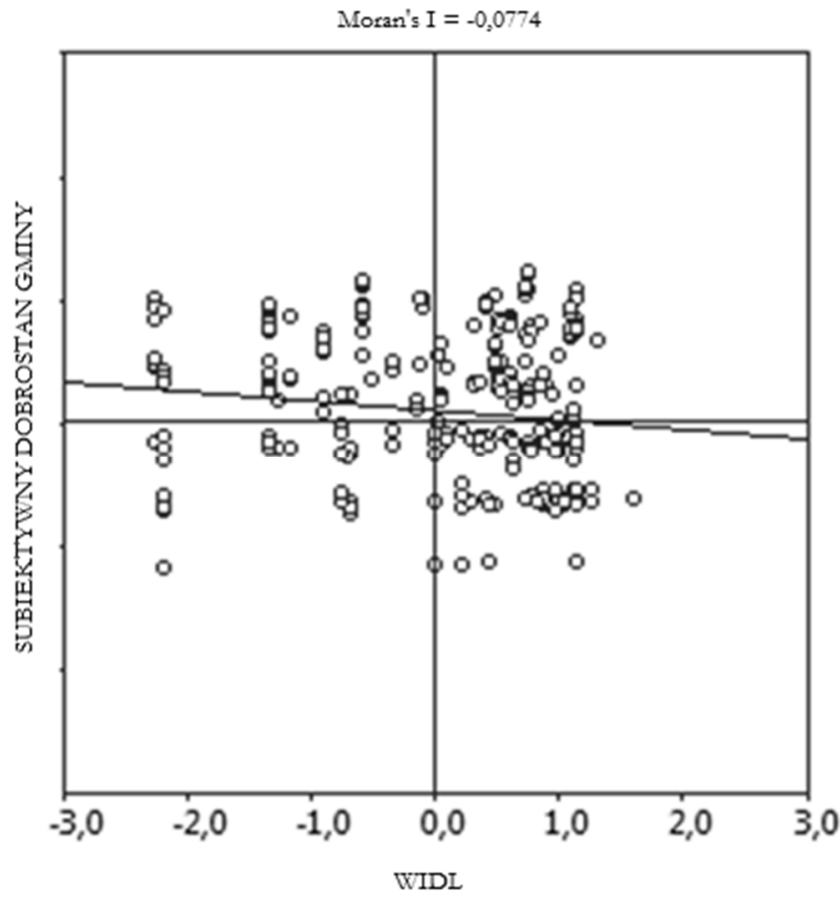

Źródło: opracowanie własne.

Ogólny kierunek zależności, wskazujący na tendencję do grupowania się gospodarstw domowych o przeciętnie wyższym poziomie dobrostanu subiektywnego w gminach zamożniejszych (o przeciętnie niższym poziomie deprywacji), potwierdza hipotetyczne oczekiwania związane z tym aspektem. Mimo to, wartość statystyki I jest zbyt mała, by przywiązywać wagę do tego wzoru zależności przestrzennej. Jednakże jest to demonstracja celowości poszukiwań tego typu zależności przestrzennych na większej (reprezentatywnej) próbie gospodarstw domowych, także jako alternatywy dla badania związków pomiędzy danymi pochodzącymi z różnego poziomu (mikro- i mezo-) za pomocą klastrów przestrzennych, zamiast modelowania wielopoziomowego („danych zagnieżdżonych”), [Subramanian, 2010].

Natomiast zdecydowanie wyraźna jest tendencja do przeważającego występowania osób deklarujących wysoki poziom dobrostanu subiektywnego w generalnie większych gminach, jak ilustruje to rysunek 10. 
RYSUNEK 10.

\section{Rozrzut Morana dla związku między wielkością populacji a subiektywnym dobrostanem gmin w województwie podkarpackim}

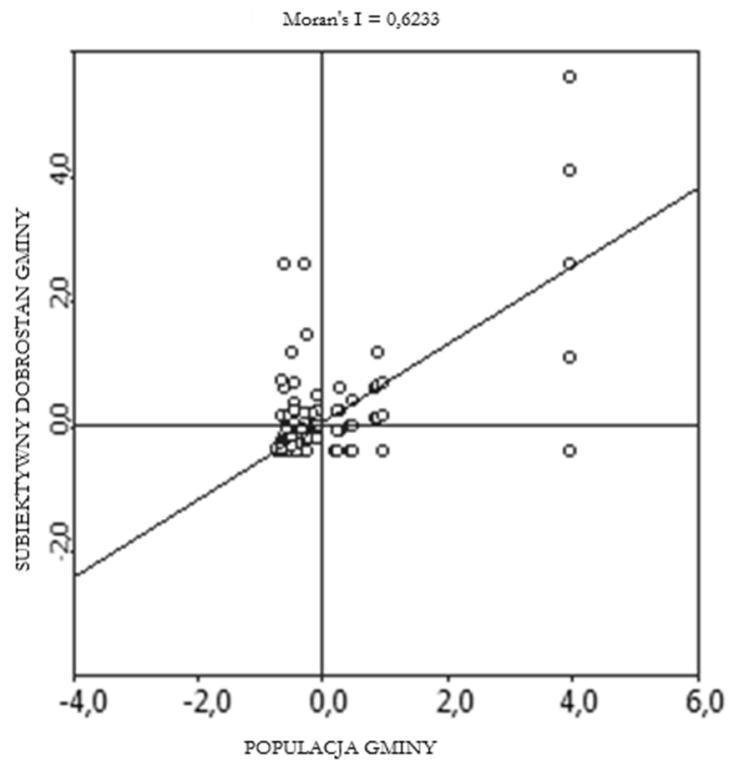

Źródło: opracowanie własne.

Zobrazowany tutaj wzór zależności przestrzennych, z silną tendencją do grupowania się obserwacji w ćwiartkach „,zgodnych” (++,--), jest bardzo podobny do wzoru na rysunku 8. Sugeruje to, że choć nie ma bezpośredniego związku „,w przestrzeni” pomiędzy deprywacja gminy a poziomem subiektywnego dobrostanu jej mieszkańców, istnieje czynnik wspólny, jakim jest wielkość populacji gminy, z którą obydwie te miary współwystępują: gminy większe nie tylko tworzą skupiska gmin zarazem zamożniejszych, ale także koncentrują się w nich mieszkańcy o przeciętnie wyższym poziomie dobrostanu subiektywnego. Natomiast z jeszcze większą intensywnością te zależności są obserwowane po stronie małych gmin - nie tylko są one mniej zamożne (według wzoru na wykresie 8.), lecz również ich mieszkańcy są generalnie mniej zadowoleni z różnych, ważnych aspektów życia, tzn. cechują się przeciętnie niższym poziomem dobrostanu subiektywnego.

\section{Dyskusja i podsumowanie}

Mimo, podkreślanego na wstępie, niekonkluzywnego charakteru przedstawionych wyników analiz w części bazującej na miarach dobrostanu subiektywnego (pochodzących z badań pilotażowych, zrealizowanych w dwóch województwach: mazowieckim i podkarpackim), pewne dane z tych rezultatów zasługują na podkreślenie, tak $\mathrm{w}$ aspekcie metodologicznym, jak i merytorycznym. 
Po pierwsze, analiza strukturalna miar nierówności, umożliwiająca odróżnienie ich „wewnątrz-” i „międzygrupowych” komponentów zróżnicowań na danym poziomie agregowania gmin (w powiatach, w ramach województw), dostarcza istotnego poszerzenia perspektywy badawczej, skoncentrowanej na nierównomierności rozkładu wybranych charakterystyk (wskaźników) rozwoju lokalnego. Wychodząc poza oszacowanie wielkości nierówności, pozwala ona na wskazanie poziomów, na jakich w polityce rozwojowej (przytoczone na wstępie) są oczekiwane „konwergencje” pomiędzy jednostkami terytorialnymi - bardziej lub mniej zaawansowanymi. Przykładowo, w latach 2008-2010 zaobserwowano zmniejszenie nierówności „między” województwami nad zmniejszeniem nierówności „wewnątrz” województw (na poziomie gmin). Analogiczne porównanie województw na poziomie powiatów służy identyfikacji odmiennych struktur nierówności („między” powiatami i ,wewnątrz” powiatów) itp.

Po drugie, obok tradycyjnego, uwzględniającego obiektywne wskaźniki (pozyskane z Banku Danych Lokalnych) sposobu charakteryzowania rozwoju lokalnego, odwołanie się do subiektywnych wskaźników dobrostanu mieszkańców (implikujące wprawdzie konieczność dysponowania dodatkowymi danymi z badań sondażowych) umożliwia interpretowanie rozwoju lokalnego, w nadawanym mu coraz częściej w literaturze, sensie holistycznym, który uwzględnia także odczucia i oceny mieszkańców. Przykładowo, pozwala to na porównywanie profilów takich ocen między województwami i spostrzeżenia typu: na Podkarpaciu wystąpiło mniejsze zróżnicowanie w zakresie ocen dotyczących życia rodzinnego oraz życia publicznego, a równocześnie, w większości kluczowych obszarów związanych z dobrostanem subiektywnym, mieszkańcy Podkarpacia byli mniej zadowoleni niż mieszkańcy Mazowsza. Przy czym, stosunkowo największa różnica pomiędzy województwami: podkarpackim i mazowieckim miała miejsce w ocenie dotyczącej dochodów osobistych.

Po trzecie, uzupełnienie analiz nierówności o analizę przestrzenną współwystępowania wybranych cech gmin i gospodarstw domowych (na poziomie gmin), dało okazję do wglądu w, pomijane na ogół, kwestie związane z rozwojem lokalnym, obejmujące tendencje do skupiania się (do tworzenia klastrów przestrzennych). Identyfikacje takich tendencji ułatwia posłużenie się statystyką I Morana (dla obliczania autokorelacji przestrzennej na danych geo-kodowanych), prowadząc do wniosków typu: istnieje tendencja do skupiania się (sąsiadowania ze soba) gmin o podobnym poziomie deprywacji (rozwoju). Ponadto, mimo braku bezpośredniego powiązania w przestrzeni (współwystępowania) pomiędzy subiektywnym dobrostanem mieszkańców a kontekstem socjo-ekonomicznym, charakteryzowanym przez indeks deprywacji lokalnej (obiektywne miary dobrostanu nie wpływaja na ich subiektywne odpowiedniki), generalnie lepsze są zarówno kontekst, jak i samoocena mieszkańców w gminie o przeciętnie większej liczbie mieszkańców.

Złożoność procesów rozwoju społeczno-gospodarczego jednostek przestrzennych ujawnia potrzebę rozwijania tego typu badań łączących indywidualny (gospodarstwa domowe) i lokalny (gminy) poziom analiz za pomocą obiektywnych i subiektywnych charakterystyk efektów rozwoju lokalnego, jakimi są właśnie złożone miary dobrostanu lokalnego. 


\section{Literatura}

Aghion P., Commander S. 1999 On the Dynamics of Inequality in the Transition, „Economics of Transition", vol. 7, no. 2.

Allison R. A., Foster J. 2004 Measuring Health Inequality Using Qualitative Data, „Journal of Health Economics", 23.

Aldstadt J. 2010 Spatial Clustering, [in:] Handbook of Applied Spatial Analysis. Software, (eds.) M. M. Fischer, A. Getis, Tools, Methods and Applications, Springer, BerlinHeidelberg.

Anand P., Krishnakumar, J., Tran N. B., Measuring Welfare: Latent Variable Models for Happiness and Capabilities in the presence of Unobservable Heterogeneity, „Journal of Public Economics", Volume 95, Issues 3-4, April 2011.

Anselin L., Syabri I., Kho Y. 2010 GeoDa: An Introduction to Spatial Data Analysis, [in:] Handbook of Applied Spatial Analysis, (eds.) M. M. Fischer, A. Getis, SpringerVerlag, Berlin-Heidelberg .

Atkinson A. B. 2003 Multidimensional Deprivation: contrasting social welfare and counting approaches, ,Journal of Economic Inequality", 1.

Handbook of Regional Growth and Development Theories 2009, (eds.) R. Capello, P. Nijkamp, Edward Elgar. Cheltenham, UK.

Chavis D. M., Lee K. S., Acosta J. D. 2008 Sense of Community (SCI): The reliability and validity of the SCI-2, Paper presented at the 2nd International Community Psychology Conference, Lisboa, Portugal, 4-6 June, 2008.

Gorzelak G. 2009 Cohesion and Convergence. Synonyms or two different notions?, [in:] Spatial Disparities and Development Policy, (eds.) G. Kohendorfer-Lucius, B. Pleskovic, The World Bank, Waszyngton.

OCSI 2008 Deprivation in rural areas: Quantitative analysis and socio-economic classification, Report for the Commission for Rural Communities, dokument elektroniczny, tryb dostępu: [http://bit.ly/xgqJN4, data wejścia: 2008].

OECD 2013 OECD Guidelines on Measuring Subjective Well-being, OECD Publishing, dokument elektroniczny, tryb dostępu: [http://dx.doi.org/10.1787/9789264191655en, data wejścia: 2013].

Okrasa W. 2013 Spatial Aspects of Community Wellbeing. Analyzing Contextual and Individual Sources of Variation using Multilevel Modeling, Referat na 59. Światowym Kongresie Statystyki w Hong Kongu, 25-30 sierpnia.

Okrasa W., Cierpiał-Wolan M., Markocki P. 2013 Statistical Issues in Analyzing TransBorder Non-Institutional Activities. Effect on Spatiallnequality of Wellbeing, Referat na 59. Światowym Kongresie Statystyki w Hong Kongu, 25-30 sierpnia.

Okrasa W., Gudaszewski G. 2013 Metropolizacja i ksz̨atcenie myższe jako cąyniki zróżnicowania dobrostanu spoteczności lokalnej: wstępna dekompozycja nierówności, Acta Universitatis Nicolai Copernici, Ekonomia XLIII, nr 1.

Okrasa W., Lapins J., Vremis M. 2006 Measuring Community Deprivation for Geographic Targeting of Public Resources - case of Moldova, „Statistics in Transition”, vol. 7, no. 5.

Rey S. J. 2004 Spatial Analysis of Regional Income Inequality, [in:] Spatially Integrated Social Science, (eds.) M. F. Goodchild, D. G. Janelle, Oxford University Press, Oxford. 
Rogalińska D. 2013 System monitorowania regionalnego STRATEG, Prezentacja na III Konwencie Marszałków Województw RP, Torun 4 grudnia 2013 roku.

Subjective Well-Being: Measuring Happiness, Suffering, and Other Dimensions of Experience. Panel on Measuring Subjective Well-Being in a Policy-Relevant Framework 2013, (eds.) A. A. Stone, Ch. Mackie, Committee on National Statistics, Division on Behavioral and Social Sciences and Education, National Research Council, Waszyngton.

Subramanian S. V. 2010 Multilevel Modeling, [in:] Handbook of Applied Spatial Analysis: Software Tools, Methods and Applications, (eds.) M. M. Fischer, A. Getis, SpringerVerlag, Berlin-Heidelberg.

Theil H. 1979 Zasady Ekonometrii, PWN, Warszawa. 